\title{
Removal Mechanisms of Slag against Potentially Toxic Elements in Soil and Plants for Sustainable Agriculture Development: A Critical Review
}

\author{
Sajid Mehmood ${ }^{1,+}+\mathbb{D}$, Xiukang Wang ${ }^{2, *}$, Waqas Ahmed ${ }^{3,4,+} \mathbb{D}$, Muhammad Imtiaz ${ }^{5}$, Allah Ditta ${ }^{6} \mathbb{D}$, \\ Muhammad Rizwan ${ }^{7}$, Sana Irshad ${ }^{8}$, Saqib Bashir ${ }^{9}$, Qudsia Saeed ${ }^{10}$, Adnan Mustafa ${ }^{11}$ and Weidong Li $^{1, *}$
}

Citation: Mehmood, S.; Wang, X.; Ahmed, W.; Imtiaz, M.; Ditta, A.; Rizwan, M.; Irshad, S.; Bashir, S.; Saeed, Q.; Mustafa, A.; et al. Removal Mechanisms of Slag against Potentially Toxic Elements in Soil and Plants for Sustainable Agriculture Development: A Critical Review. Sustainability 2021, 13, 5255. https://doi.org/10.3390/su13095255

Academic Editors: Marc A. Rosen and Mohamed A. El-Esawi

Received: 21 March 2021

Accepted: 5 May 2021

Published: 8 May 2021

Publisher's Note: MDPI stays neutral with regard to jurisdictional claims in published maps and institutional affiliations.

Copyright: (c) 2021 by the authors Licensee MDPI, Basel, Switzerland. This article is an open access article distributed under the terms and conditions of the Creative Commons Attribution (CC BY) license (https:// creativecommons.org/licenses/by/ $4.0 /)$
College of Ecology and Environment, Hainan University, Haikou 570100, China; drsajid@gzhu.edu.cn 2 College of Life Sciences, Yan'an University, Yan'an 716000, China

3 Guangdong Provincial Key Laboratory for Radionuclides Pollution Control and Resources, School of Environmental Science and Engineering, Guangzhou University, Guangzhou 510006, China; drwaqas@gzhu.edu.cn

4 School of Civil Engineering, Guangzhou University, Guangzhou 510006, China

5 Soil and Environmental Biotechnology Division, National Institute for Biotechnology and Genetic Engineering, Faisalabad 38000, Pakistan; m.imtiazpk92@hotmail.com

6 Department of Environmental Sciences, Shaheed Benazir Bhutto University Sheringal, Dir (U), Khyber Pakhtunkhwa 18000, Pakistan; allah.ditta@sbbu.edu.pk

7 Institute of Soil Science, PMAS-Arid Agriculture University, Rawalpindi 46600, Pakistan; m.rizwan110@outlook.com

8 School of Environmental Studies, China University of Geosciences, Wuhan 430070, China; sanairshad55@gmail.com

9 Department of Soil and Environmental Science, Ghazi University, Dera Ghazi Khan 32200, Pakistan; saqibbashir416@yahoo.com

10 College of Natural Resources and Environment, Northwest Agriculture and Forestry University, Yangling 712100, China; syedaqudsia.saeed@yahoo.com

11 National Engineering Laboratory for Improving Quality of Arable Land, Institute of Agricultural Resources and Regional Planning, Chinese Academy of Agricultural Sciences, Beijing 100081, China; adnanmustafa780@gmail.com

* Correspondence: wangxiukang@yau.edu.cn (X.W.); 994362@hainanu.edu.cn (W.L.)

+ These authors contributed equally to this work.

Abstract: Potentially toxic element (PTE) pollution is a major abiotic stress, which reduces plant growth and affects food quality by entering the food chain, and ultimately poses hazards to human health. Currently, the use of slag in PTE-contaminated soils has been reported to reduce PTEs and toxicity in plants. This review highlights the role of slag used as a fertilizer for better crop production and sustainable agricultural development. The application of slag increased the growth, yield, and quality of crops under PTE toxicity. The mechanisms followed by slag are the immobilization of PTEs in the soil, enhancement of soil pH, changes in the redox state of PTEs, and positive changes in soil physicochemical and biological properties under PTE toxicity. Nevertheless, these processes are influenced by the plant species, growth conditions, imposition length of stress, and type of slag used. The current review provides an insight into improving plant tolerance to PTE toxicity by slag-based fertilizer application and highlights the theoretical basis for applying slag in PTE-contaminated environments worldwide.

Keywords: slag; immobilization; plant; potentially toxic elements; tolerance

\section{Introduction}

With the rapid increase in the world population, similarly to other industries, steel industries are also more concerned about the safe and eco-friendly recycling of their byproducts. In the past, steel industries were designed to produce iron and steel of a specific quality and quantity [1]. With the rapid growth of industrialization in recent decades, the 
increased volume of byproducts (slag) produced from iron/steel production has drawn attention to the need for its more effective recycling. [1]. Slags are widely used worldwide as a substitute for limestone and offer a cost-effective advantage to farmers. The main aim for researchers and environmentalists is to stop the entry of metals and metalloids into the food chain for better human health [2,3], and in this respect, the use of slags in various fields can help cope with this problem [2]. Potentially toxic element (PTE) contamination of soil refers to the excessive deposition of PTEs due to human activities [3-6]. In soil medium, the highest concentrations of PTE plant toxicity are represented by cadmium [7], lead [7], zinc [8], copper [9], nickel [10], vanadium [11], and arsenic [12], etc.

In the current scenario, the need for food is increased, and the use of fertilizers has been increased by humans, resulting in the deterioration of the environment [13-15]. Highly mobile PTEs can easily enrich the food chain and are highly hazardous to the environment. The remediation of soil becomes very difficult once it becomes polluted with PTEs. Soil cleanup is more complicated than air and water cleanup, according to previous reports [16], because PTEs in the soil form complexes and bonds with clay particles, and it becomes more challenging to break those bonds [17]. However, soil contamination in developed countries is considered a severe issue and more attention is paid to its remediation and public health. A wide range of compounds $\left(\mathrm{TiO}_{2}, \mathrm{Fe}_{3} \mathrm{O}_{3}, \mathrm{FeO}, \mathrm{Fe}_{3} \mathrm{O}_{4}, \mathrm{BaO}, \mathrm{MgO}, \mathrm{CaO}\right.$, $\mathrm{Al}_{2} \mathrm{O}_{3}, \mathrm{MnO}$ and $\mathrm{SiO}_{2}$ ) and minerals are found on/in the layers of slags produced in various industrial operations [18,19]. In 2014, it was observed that each ton of steel produced by the steel industry generates $500 \mathrm{~kg}$ of steel slag [20]. China utilizes only $25 \%$ of steel slag out of 100 million tons produced, the production of steel slag accounting for $24 \%$ of the total solid waste produced in China [21,22]. Steel slag contains a variety of trace elements on its surface, which makes it an excellent fertilizer for better plant growth. Bearing in mind the importance of these benefits, Japan and Europe use steel slag as a soil amendment agent. Slag is used as a fertilizer and ground shifting agent in Japan and Europe because trace metal elements, such as $\mathrm{Cr}$ and $\mathrm{V}$, are not readily released in slag. [23,24]. Slag fertilizers include slag-silicate fertilizers, slag-phosphate fertilizers, and unique iron matter fertilizers [4]. The presence of $\mathrm{Ca}^{2+}$ on the surface of steel slag produces stable PTE ions, with the aim to eliminate PTE ions from the contaminated medium.

Moreover, Wen et al. [25] concluded that applying steel slag to PTE acidic mining soils effectively raises the soil's $\mathrm{pH}$, increases soil microbial abundance, and immobilizes PTE ions, providing a desirable plant survival climate. Recently, a variety of studies have reported that there is a great commitment from slag-based fertilizer modification in agriculture to increase crop productivity [26,27], minimize soil acidification [28], and alleviate greenhouse gas (GHG). Slag fertilization's beneficial results focus primarily on the shifts in microbial environments and microbial behaviors. In particular, soil microorganisms play a key role in almost all ecological processes at a system level and provide ecosystem services necessary for preserving soil quality and productivity [29]. Das et al. [1] reported that slag utilization in the PTE-contaminated soil improves crop production by affecting soil $\mathrm{pH}$ and greenhouse gas emissions. The fundamental processes of slag-microbial interactions and the importance of soil biota to ecosystem functionality are gradually deceptive. This review discussed the role of slag on PTEs used as a substitute for fertilizers for better crop growth in PTE-polluted soils.

\section{Slags as Low-Cost Adsorbents: Applications and Performance}

The adsorption and reactivity processes of the slag surfaces with adsorbates are determined by the chemical composition; morphological phases; physical properties; and other properties, such as the number of adsorption sites and form of surface functional groups. For example, the dissolution of free lime in slag regulates the $\mathrm{pH}$ of the solution and the hydrolysis of the dissolved cations $[30,31]$. Furthermore, the processes of bonding with adsorbates in slags are dictated by the hydrolysis products of different chemical phases [32] The type of slag and its particle size distribution impact potentially toxic elements' (PTEs) adsorption efficiency. A porous slag system with a micropore size distribution produces 
a broad internal surface region, resulting in strong adsorption potential and adsorption performance [32-35]. The adsorption potential of slags is also affected by experimental conditions, such as agitation rate, temperature, and solid/liquid phase ratio, and solution conditions, such as solution $\mathrm{pH}$, adsorbate types and concentration, ionic pressure, and competing adsorbates [33]. This segment offers a comprehensive overview of existing information regarding the adsorption of PTEs and other adsorbates by slags.

\section{Slag as an Amendment}

\subsection{Effects on Potentially Toxic Elements in Plants}

Plant growth and yield are high priorities for sustainable agricultural progress [36]. In recent decades, plant growth and human health are at high risk due to the contamination of soils with potentially toxic elements (PTEs). The toxicity caused by PTEs to the plants in PTE-polluted environments can be predicted by bioavailability [37]. Fractions of PTEs in the soil play a vital role in the uptake of PTEs by plants. The most stable form of PTE is the residual fraction, which forms crystals with soil minerals and becomes unavailable to plants [38]. While the acid-soluble fraction of PTEs induces toxicity due to its easy uptake by plants, with the addition of amendments, such as slag, it can be immobilized. Liu et al. [39] reported that the acid-soluble fraction of As could be immobilized with the addition of different kinds of slags.

Furthermore, Wang et al. [40] reported that the maturity of soil also promotes the sorption of PTEs with the increase in soil redox potential. With the addition of slag to the Cd-polluted site at two separate crop growth levels, the bioavailability of $\mathrm{Cd}$ was reduced. [35], while reducible and oxidizable fractions of PTEs in the soil are unstable and can be changed with the change in soil conditions [41,42]. The addition of slags to $\mathrm{Cd}-$ and As-contaminated soil increased the oxidizable fractions and decreased the reducible fractions of both the metals by increasing soil $\mathrm{pH}$ [43]; this may refer to the adsorption of PTEs with Fe/Mn oxides in soil (Figure 1). It was noted by Liu et al. [35] that the addition of slag to a rice crop in contaminated soil decreased its concentration by $40 \%$ in roots and 38\% in shoots. The use of slag as a fertilizer increases phosphorus [44], calcium, and magnesium [45] availability to the plants. Calcium and magnesium form inorganic ionic pairs with minerals present on the slag surface used as a fertilizer [46-48]. It was concluded by Fan et al. [49] that the use of slag as a fertilizer has the ability to decrease $\mathrm{Cr}, \mathrm{Cu}, \mathrm{Pb}$, and $\mathrm{Zn}$ in acidic soils and indicated that slag could be used in PTE pollution control for plants and the environment. Fan et al. [49] further concluded that slag fertilization is risk-free for surrounding soils and plants. However, the use of slag as a fertilizer at the field level necessitates more empirical results to be obtained and the more in-depth prediction of the role of this fertilizer against other chemical fertilizers used for the remediation of PTEs from PTE-polluted sites.

\subsection{Effects on Crop Yield}

In China, food safety has gained great public concern with the frequently published reports on environmental contamination effects on crop quality [50,51]. According to the Chinese ministry of health, the rice samples from various markets across the country exceed the permissible limit of $\mathrm{Cd}$ in rice [52,53]. According to Du et al. [54], approximately $60 \%$ of the rice samples collected from Hunan province were found to be unfit according to the permissible $\mathrm{Cd}$ limit. The use of slag fertilization is gaining a large amount interest and demand around the globe. Silicate-based slags are commonly used in rice cropping systems [55], as Si is considered essential for plants [1]. The intensive rice cultivation in many countries, such as China, to meet food demand is depleting Si from the soil, which causes a reduction in the yield of crops and affects soil health [56]. This makes applying silicate fertilizers to rice crops necessary to achieve better yields [1]. Many studies have reported an increase in rice yield using silicate-based slag as a fertilizer in lowlands fields. However, the increase in the yields of grains is directly proportional to the types of slag, 
their application percentage, the type of soil, and agronomic management [1]. The potential effect of slag on crop yield is presented in Table 1.

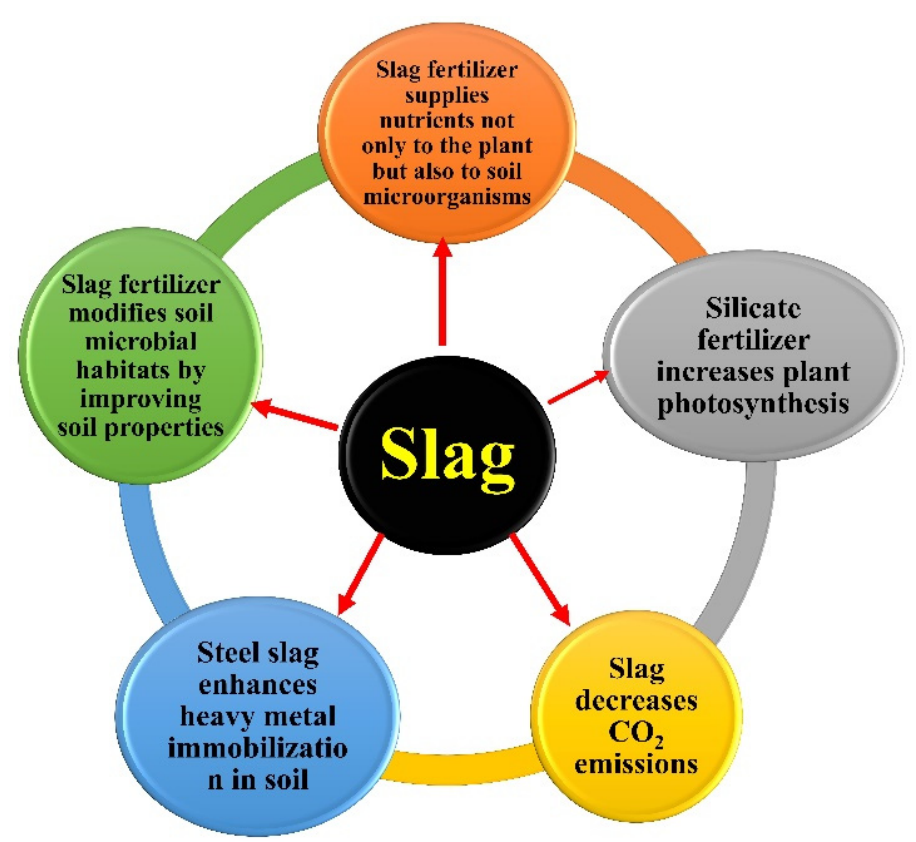

Figure 1. Beneficial effects of slag-based fertilizers in soil and plant.

Table 1. Potential effects of slag-based fertilizers on crop yield.

\begin{tabular}{|c|c|c|c|c|c|}
\hline \multirow{2}{*}{ Types of Slag Used } & \multicolumn{2}{|c|}{ Yield } & \multirow{2}{*}{$\begin{array}{l}\text { Application } \\
\text { Rate }\end{array}$} & \multirow{2}{*}{$\begin{array}{c}\text { Duration } \\
\text { of Trial }\end{array}$} & \multirow{2}{*}{ References } \\
\hline & Control & Slag & & & \\
\hline & \multicolumn{2}{|c|}{ g/ha } & $\mu \mathrm{g} / \mathrm{ha}$ & Years & \\
\hline Silicate iron slag & 6000 & 7140 & 4000 & 2 & [57] \\
\hline Silicate fertilizer & 6450 & 9450 & 4000 & 1 & [58] \\
\hline carbide slag & $7.53 \times 10^{6}$ & $8.61 \times 10^{6}$ & $3 \times 10^{6}$ & 1 & [39] \\
\hline $\begin{array}{l}\text { Silicate fertilizer } \\
\text { (granular) }\end{array}$ & 3900 & 4500 & 2300 & 1 & [59] \\
\hline $\begin{array}{l}\text { Silicate fertilizer } \\
\quad \text { (granular) }\end{array}$ & 5200 & 5600 & 2300 & 1 & [59] \\
\hline $\begin{array}{l}\text { Silicate fertilizer } \\
\quad \text { (granular) }\end{array}$ & 5300 & 5900 & 2300 & 1 & [59] \\
\hline $\begin{array}{l}\text { Silicate fertilizer } \\
\text { (granular) }\end{array}$ & 5160 & 5600 & 2300 & 1 & [59] \\
\hline Steel slag & 6730 & 6830 & 8000 & 1 & [60] \\
\hline $\begin{array}{l}\text { Silicate fertilizer } \\
\text { (granular) }\end{array}$ & 12,580 & 12,600 & 2000 & 2 & [61] \\
\hline Steel slag & 4630 & 4670 & 8000 & 1 & [60] \\
\hline $\begin{array}{l}\text { Silicate fertilizer } \\
\quad \text { (granular) }\end{array}$ & 12,580 & 12,840 & 4000 & 2 & [61] \\
\hline $\begin{array}{l}\text { Silicate fertilizer } \\
\quad \text { (granular) }\end{array}$ & 12,580 & 12,850 & 8000 & 2 & [61] \\
\hline Steel slag & 4910 & 5060 & 8000 & 1 & [60] \\
\hline Steel slag & 6970 & 7200 & 8000 & 1 & [60] \\
\hline LD slag & $5.7 \mathrm{~g} \mathrm{pot}^{-1}$ & $6.3 \mathrm{~g} \mathrm{pot}^{-1}$ & 2000 & 1 & [26] \\
\hline
\end{tabular}

According to Ali et al. [58], the application of silicate-based fertilizers in submerged paddies could increase $47.3 \%$ of the crop yield. However, Luyckx et al. [62] further reported that $\mathrm{Si}$ from the applied silicate fertilizers in the soil preferentially deposits in the epidermal 
cell wall of the plant to increase its strength, help to sustain various other stresses, and increase plant biomass. Similarly, lime-based slag fertilizers are used in acidic soil to change the acidic nature of soils which benefits plants in terms of mineral availability and provides protection to plants against pathogens. Phosphate-based slag fertilization improves initial plant growth and yield by increasing the level of phosphorous in the soil. Moreover, slag is loaded with Ca on its surface, which provides strength to plant roots and improves the $\mathrm{K}$ uptake, which is essential for the growth of plants [53]. Calcium silicate-based slag decreases the $\mathrm{pH}$ of the soil and has also been found to increase the bioavailbilty of $\mathrm{P}$, $\mathrm{Si}$, and Ca present in soil [63]. The slag produced from the blast furnace was used in rice plants and was found to increase growth, biomass, and yield by improving the soil fertility status [64]. A mixture of converter slag and fungicide does not reduce the density of Plasmodiophora brassicae in soil but rather eliminates clubroot fungus [65]. The use of Linz-Donawitz (LD) slag in acidic pastured soils raises soil $\mathrm{pH}$; increases $\mathrm{Ca}$ and $\mathrm{Mg}$ soil exchangeability; decreases equivalents $\mathrm{Al}, \mathrm{Mn}, \mathrm{Cu}$, and $\mathrm{Zn}$ in soils; and results in significant crop yield and nutrient optimal concentrations in plants [66]. Brazilian sugarcane fields with both calcite and basic slags have a positive residual impact on soil acidity adjustment, increased base saturation, and the sugarcane yield of ratoon [67]. The increase in crop yield with the fertilization of slag in soil is largely regulated by the microbial decomposition of organic matter and nutrient mobilization [1]. Das et al. [1] further reported that the fertilization of slag not only increases soil nutrients, but also enriches soil microorganisms that have a beneficial role in nutrient mobilization. Therefore, it is necessary to determine the role of soil microbes that influence different plant physiologies under slag amendments for better agricultural productivity under slag application. The potential effect of slag on plant growth is presented in Figure 2.

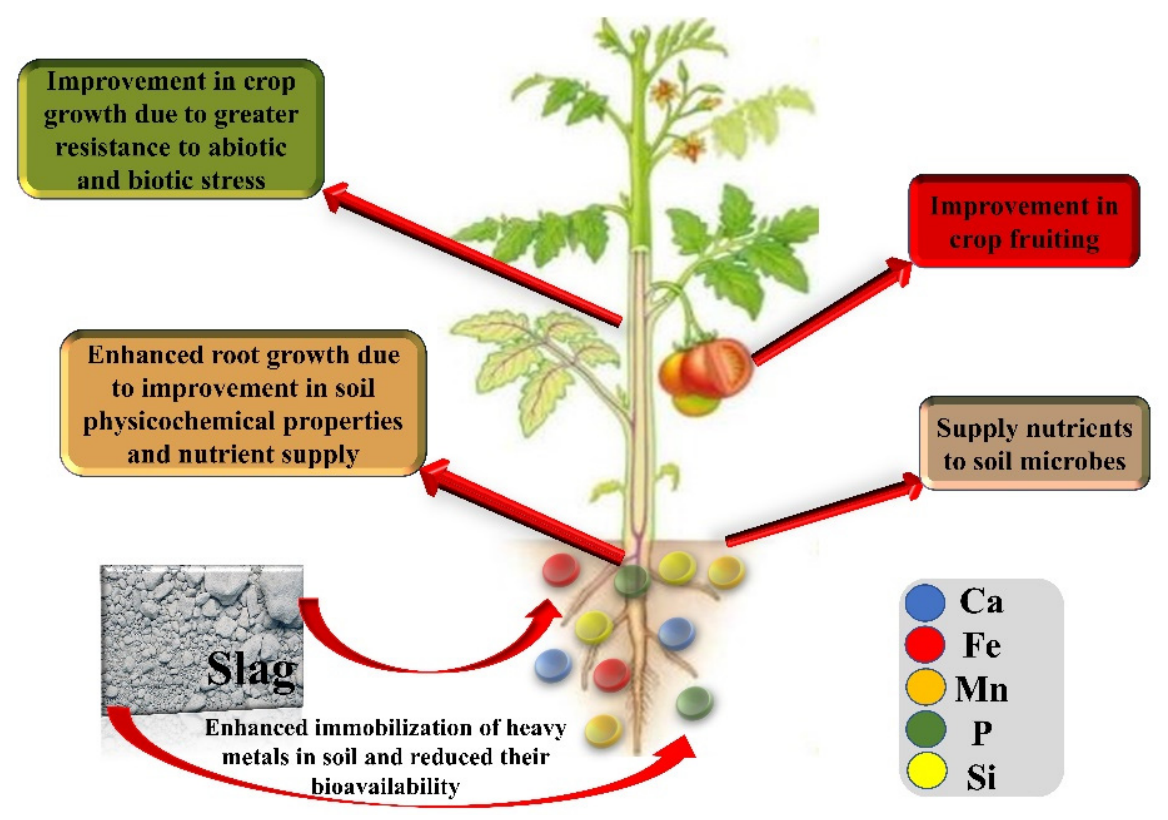

Figure 2. The potential effect of slag on plant growth.

\subsection{Effects on Potentially Toxic Elements in Soils}

The PTEs in agricultural soils are constantly increasing with fertilizers and pest control agents, coal combustion of materials rich in PTEs, irrigation of soil with sewage water, and mining [68]. Among these, the irrigation of soils with sewage water proved to be the most destructive in terms of PTE concentration increment. The potential toxicity of elements in the soil is mainly caused by sewage irrigation [68]. According to 55 surveyed sites in China by the First National Survey of Soil Pollution (FNSSP) in 2005-2013, about 39 were irrigated by sewage water [69]. Titanium (Ti) contamination in arable soils of Guangdong province resulted from long-term wastewater irrigation [70]. The toxicity of metals/metalloids 
can be reduced by changing soil properties with slag amendment through adsorption, precipitation, cation/anion exchange, and by changing soil $\mathrm{pH}$. This method helps reduce bioavailable PTEs, such as $\mathrm{As}, \mathrm{Cu}, \mathrm{Pb}, \mathrm{Cd}$, and $\mathrm{Zn}$ [18]. Masud et al. [71] also reported that the inclusion of slag in the soil could improve its properties, such as $\mathrm{pH}$, electrical conductivity (EC), cation exchange capacity (CEC), exchangeable $\mathrm{Ca}, \mathrm{Mg}$, and metal availability to the plant, and as a result, proved helpful in increasing the crop yield. There are several examples: Fe oxyhydroxide sorption and the formation of amorphous Fe (III) arsenates can stabilize $\mathrm{Fe}$; $\mathrm{Cr}$ can be stabilized by reducing the more mobile toxic $\mathrm{Cr}$ (VI) (III); $\mathrm{Cu}$ carbonate and oxyhydroxide precipitation, ion exchange, and the formation of the ternary cation-anion complex on the surface of $\mathrm{Fe}$ and $\mathrm{Al}$ oxyhydroxides can all stabilize $\mathrm{Cu}$; and phosphorus changes to $\mathrm{Pb}$ and $\mathrm{Zn}$ may also stabilize $\mathrm{Cr}$ (III) [52]. Soil amendment with slag as a fertilizer significantly alters soil solution composition by either precipitation or sorption reactions. Ning et al. [28] concluded that slag fertilization to metal-polluted soil stabilizes the chemical and mineralogical properties of PTEs.

Additionally, slag fertilization in soil increases Si supply which plays a crucial role against the alleviation of As uptake by crops [51]. The application of passivators (Thomas basic slag (TBS), hydrous manganese oxide (HMO), and iron ores) to $\mathrm{Cd}-, \mathrm{Pb}-$, and $\mathrm{Zn}$ contaminated soil showed a smaller improvement of plant biomass but significantly decreases the toxicity levels of these PTEs in plants [58]. These agents minimize the consumption of $\mathrm{Cd}$ by plants efficiently. $\mathrm{HMO}$ and iron ores help to minimize shoot $\mathrm{Pb}$ or $\mathrm{Zn}$ levels in ryegrass, while TBS decreases shoot $\mathrm{Pb}$ concentration. The $\mathrm{Ca}$ and $\mathrm{C}$ content in TBS improves crop yields and the physicochemical properties of the soil by increasing the precipitation and sorption of PTEs [1].

\subsection{Effects on Soil Properties Subjected to Immobilization of Potentially Toxic Elements}

Soil contamination by PTEs has become a global concern and needs urgent solving for better crop production. A wide range of approaches has been employed for the improvement of soil quality and crop yield. According to Gao et al. [72], the wastewater generated from the burning of fossils, sewage, application of pesticides, etc., is the main source of the river, groundwater, and soil pollution. The application of slag as an amendment in co-contaminated soil changes the forms of PTE and properties of soils significantly. According to Qin et al. [60], these changes are attributed to an increase in soil $\mathrm{pH}$ due to the loading of slag surface $\mathrm{NaOH}, \mathrm{CaCO}_{3}, \mathrm{Ca}$, and $\mathrm{Mg}$ oxides. It was also confirmed by Liu et al. [35] that slag application in the soils causes an increase in soil pH. Slags with higher components of $\mathrm{Ca}$ and $\mathrm{Mg}$ oxides (carbide slags) are the best choice for their application in acidic contaminated soils as they increase soil $\mathrm{pH}$ and change forms of various PTEs. Additionally, a slag with a higher amount of $\mathrm{Ca}, \mathrm{Mg}$, and $\mathrm{Si}$ on its surface precipitate PTEs present in the PTE-polluted soils [73-75]. Acidic soil promotes the adsorption of As anions, while high-pH soils caused desorption in As anions by decreasing positive charges [76,77]. Tang [78] concluded that the bioavailability of As could be significantly affected by increasing soil $\mathrm{pH}$. A two-year field study found that the application of slag from the steel industry as an amendment causes significant changes in soil physicochemical properties, such as enhancement in soil $\mathrm{pH}$, soil organic carbon contents, stabilize soil carbon, and soil salinity, and alters the communities of bacteria present in the soil [35]. Hence, waste materials, such as slag, can be used as an amendment to the polluted agricultural soils to improve soil fertility, crop growth, and fruiting. However, the mechanism of slag interaction with microbes in soil and their effect on carbon cycling is still limited and needs to be addressed.

\subsection{Effects on Soil Organic Carbon Contents}

Soil organic matter plays an important role in the remediation of PTEs from polluted environments, provides essential nutrients to plants, and improves plant growth and fruiting. The long-term application of slag to the soil increases soil organic carbon contents due to lower carbon mineralization rates [79]. Additionally, slag contains ferric oxide on its surface, which could also increase soil carbon storage [80,81]. Downward movement 
of the slag causes a higher increment in soil organic contents in the deeper horizon as compared to topsoil $[82,83]$. Slag fertilization may decrease the labile $C$ availability for microorganisms as slag shows very poor performance in organic minerals [84,85]. Wang et al. [79] found a negative correlation between soil $\mathrm{pH}$ and soil microbial biomass carbon. Soil $\mathrm{pH}$ is considered crucial for microbial growth [86]. However, different bacteria respond differently to soil pH changes [87]. According to Wang et al. [79], certain acidophilic microorganisms' activity was suppressed with increased soil pH due to slag application.

\section{Mechanism of Slag Interaction with Potentially Toxic Elements in Soil}

Bearing in mind the application benefits of slag-based fertilizers for better crop production in potentially toxic element (PTE)-contaminated soils, it is important to know the different mechanisms slag follows to bind toxic ions at the soil and plant levels (Figure 3). Many studies have mentioned the mechanisms of detoxification of PTEs in plants by slag. However, a better understanding of the mechanism of PTE detoxification in plants from contaminated soils is vital for the practical application of slag. At the soil level, the application of slag may cause the immobilization of PTE, changes in the soil $\mathrm{pH}$, and changes in PTE fractions, and causes an improvement in the soil physicochemical and biological properties of soils. While at the plant level, the application of slag-based fertilizers causes an increase in the antioxidant defense system and causes a reduction in the translocation of PTEs to plant shoots.

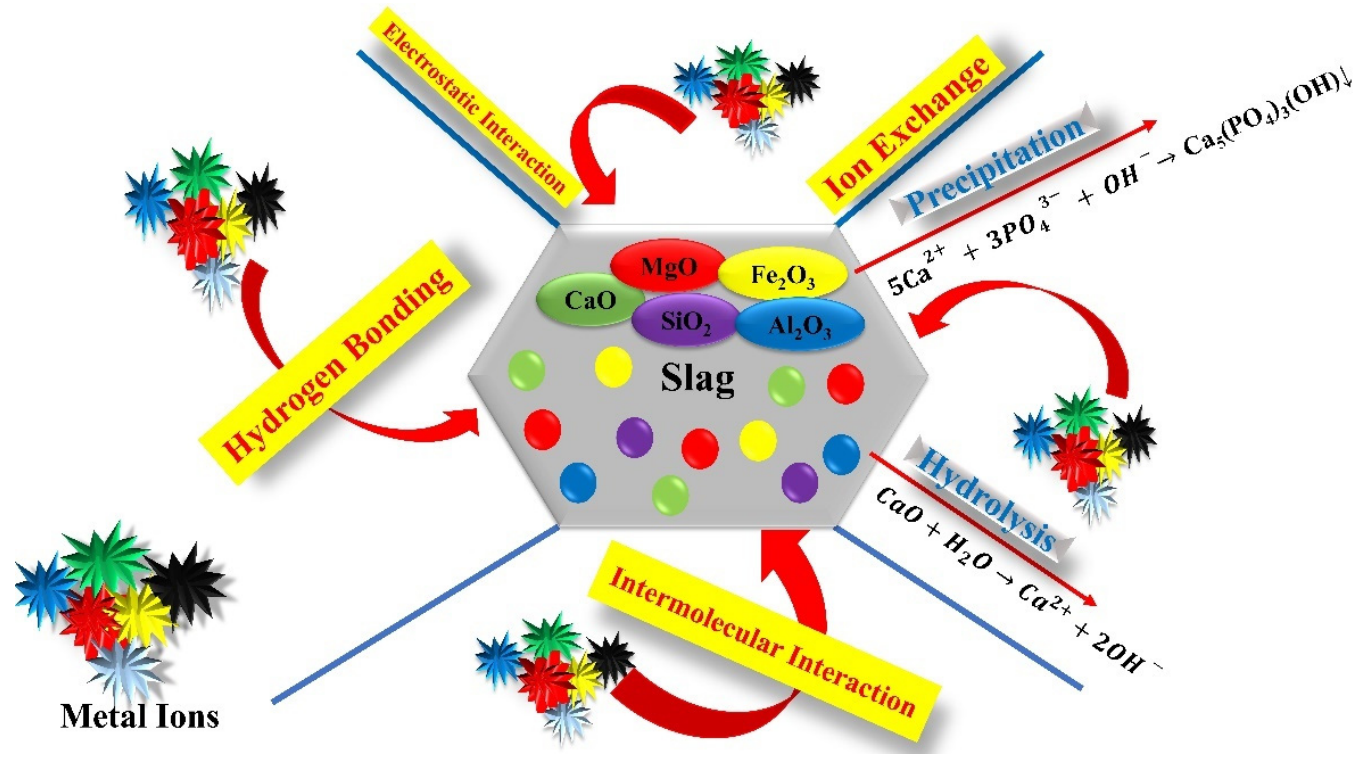

Figure 3. Proposed mechanism of slag-based fertilizers in the soil.

However, the mechanisms for PTE ion remediation by slag are similar to many other applied amendments in previous studies, such as lime [88], biochar [89-92], zeolite [93], chitosan [94], the indigenous strain Bacillus XZM [95], hydrogen sulfide [96], and sepiolite [97]. The basic PTE ion immobilization on the slag surface was attributed to the presence of silicate, ferrites, and calcium oxides on the surface [98]. Silicate ferrite present on the slag surface releases $\mathrm{SiO}_{4}{ }^{4-}$ and $\mathrm{Fe}_{2} \mathrm{O}_{3}$, and $\mathrm{OH}^{-}$interacts with PTE ions to make them immobile [98]. The presence of hydrogen oxides on the surface of slag has the ability to diffuse into the slag surface [98] due to small masses [99] and then can immobilize PTEs on the slag surface [100]. Moreover, PTEs exchange with the silicate and ferrite present on the slag surface and can be immobilized within the slag matrix [101]. The PTE ions present in the soil solution gradually enter the slag due to the absorption gradient.

Additionally, various metals form complexes with soil organic matter and become immobilized due to increased organic matter after slag addition to the soils. The increase in soil pH might result in the instability of PTE ion concentration in soil solutions. The 
unstable PTEs in the soil solutions exchange with $\mathrm{Ca}^{2+}$ in order to be immobilized within the silicate and ferrite fractions [100], while some PTE ions make bonds in soil organic matters. Moreover, various cations and anions are present on the slag surface, which increases the ionic strength and may affect PTE species. However, there are still unresolved areas for further studies to analyze the effects of ionic strength on the immobilization mechanism of PTEs under the slag-based fertilization of acidic polluting soils.

\section{Concerns about the Fertilization of Slag for Sustainable Agriculture}

The use of slag fertilizers to improve crop production and soil fertility in contaminated media is a beneficial product for sustainable agriculture [1]. These effects might be related to the change in soil microorganisms and nutrients with slag in the contaminated soil. However, the fertilization of potentially toxic element (PTE)-contaminated soils with slags is considered at risk of PTE accumulation and liming [3]. The accumulation of PTEs in the soil may cause deleterious effects on human health; however, according to Gwon et al. [28], the slags contain traces of PTEs, but their concentration might not cause environmental hazards. According to previous studies, the short-term application of slag as a fertilizer proved beneficial for plants in contaminated soils [29]. However, the long-term application of slag significantly increased the levels of $\mathrm{Cr}$ and $\mathrm{V}$ in the soil-cultivated layer.

In contrast, Hiltunen [102] investigated the long-term effect of slag in Germany and concluded that the slag amendment did not enhance the levels of $\mathrm{Cr}$ in soil and uptake by plants. Therefore, there is a great need to perform research on the long-term application of slag to analyze its effect on agriculture under different contaminated soils and agronomic management practices. The excessive fertilization of contaminated soils with slag may increase alkalinity in the soil, which results in a reduction in the uptake of essential macroand micronutrients by plants and causes a reduction in crop yield [103]. The application of slag as a fertilizer may reduce plant growth because $\mathrm{N}, \mathrm{P}$, and $\mathrm{K}$ on the slag surface are very low. Therefore, slag and chemical fertilizers with high $\mathrm{N}, \mathrm{P}$, and $\mathrm{K}$ levels should be considered for better crop production [1,104,105].

\section{Conclusions and Future Directions}

Potentially toxic elements (PTEs) significantly decrease crop yields and cause a huge loss to the productivity of agriculture, with a severe threat to humans and animals by entering the food chain via these crops. In recent decades, it has been reviewed that the application of slag fertilizers could be helpful in the significant removal of PTE ions from plants and soils. The application of slag to PTE-polluted soils decreased PTE uptake by plants and significantly improved plant growth and yield. The mechanisms of PTE removal by slag include: (a) the immobilization of PTEs by sorption and increase in soil $\mathrm{pH}$; (b) changing the fraction of PTEs in the soil; (c) changing soil physicochemical and biological properties; (d) the alteration of plant antioxidant enzymes. However, these mechanisms can be different for different plants, genotypes of plants, plant growth conditions, imposition time of stress, and types of slag fertilizers used. Therefore, slag as a fertilizer can be used as a soil remediator for better crop growth. The purpose of this review was to highlight the importance of slag as a fertilizer to be used against PTE-contaminated sites for sustainable agricultural development and for the reduction in PTEs in plants to stop their entrance into the food chain. However, more work is required on the mechanism of slag interaction with PTEs in plants. Freshly obtained slag has been applied recently in many studies; however, the application of slag in the soil might undergo many biochemical interactions, and its effect on the soil with age might vary. There is still a need to analyze the effect of aged slag on PTE bioavailability to better understand this phenomenon. Some of the studies mentioned above pointed out the adsorption of PTEs on the slag surface and also retained nutrients. This showed that certain slag applications as fertilizers in PTE-contaminated soil might cause a reduction in plant growth and production due to the lower availability of nutrients. The effect of slag fertilization on PTE-contaminated soils concerning nutrient availability for plants must be evaluated in the future. The abovementioned research 
explained that the fertilization of PTE-contaminated soils with slag showed a modification in plant growth, but there is still a research gap on whether the aged slag could have the same effect as fresh slag.

Furthermore, the effect of aged slag fertilization on the adsorption and immobilization of PTEs in soil and the bioavailability of PTEs in contaminated soil is also unclear. Finally, it is recommended to conduct lab trials of aged slag fertilization before its long-term application for sustainable agriculture. In conclusion, field trials of aged slag are required to establish a strong role of slag in the remediation of PTEs from contaminated environments.

Author Contributions: Conceptualization, S.M. and W.L.; methodology, W.A. and S.M.; validation, X.W., M.I., M.R. and Q.S.; formal analysis, S.M. and S.I.; investigation, W.L., S.M. and A.M.; data curation, A.D. and S.B.; writing-original draft preparation, W.A. and S.M. All authors have read and agreed to the published version of the manuscript.

Funding: This research received no external funding.

Institutional Review Board Statement: Not applicable.

Informed Consent Statement: Not applicable.

Data Availability Statement: No new data were created or analyzed in this study. Data sharing is not applicable to this article.

Acknowledgments: The National Natural Science Foundation of China (NSFC-31860728) economically supported this research.

Conflicts of Interest: The authors declare no conflict of interest.

\section{References}

1. Das, S.; Kim, G.W.; Hwang, H.Y.; Verma, P.P.; Kim, P.J. Cropping With Slag to Address Soil, Environment, and Food Security. Front. Microbiol. 2019, 10, 1320. [CrossRef]

2. Kimio, I. Steelmaking Slag for Fertilizer Usage. Nippon. STEEL SUMITOMO Met. Tech. Rep. 2015, 109, 130-136.

3. Brevik, E.C.; Burgess, L.C. Soils and Human Health. In Soils and Human Health; CRC Press: Boca Raton, FL, USA, $2012 ;$ pp. 1-403. ISBN 9781439844557.

4. Chowdhury, S.; Mazumder, M.J.; Al-Attas, O.; Husain, T. Heavy metals in drinking water: Occurrences, implications, and future needs in developing countries. Sci. Total Environ. 2016, 569-570, 476-488. [CrossRef]

5. Dixit, R.; Wasiullah; Malaviya, D.; Pandiyan, K.; Singh, U.B.; Sahu, A.; Shukla, R.; Singh, B.P.; Rai, J.P.; Sharma, P.K.; et al. Bioremediation of heavy metals from soil and aquatic environment: An overview of principles and criteria of fundamental processes. Sustainability 2015, 7, 2189-2212. [CrossRef]

6. Rascio, N.; Navari-Izzo, F. Heavy metal hyperaccumulating plants: How and why do they do it? And what makes them so interesting? Plant Sci. 2011, 180, 169-181. [CrossRef]

7. Mehmood, S.; Rizwan, M.; Bashir, S.; Ditta, A.; Aziz, O.; Yong, L.Z.; Dai, Z.; Akmal, M.; Ahmed, W.; Adeel, M.; et al. Comparative Effects of Biochar, Slag and Ferrous-Mn Ore on Lead and Cadmium Immobilization in Soil. Bull. Environ. Contam. Toxicol. 2017, 100, 286-292. [CrossRef]

8. Hafeez, B.; Khanif, Y.M.; Saleem, M. Role of Zinc in Plant Nutrition-A Review. Am. J. Exp. Agric. 2013, 3, 374-391. [CrossRef]

9. Bashir, S.; Zhu, J.; Fu, Q.; Hu, H. Comparing the adsorption mechanism of Cd by rice straw pristine and KOH-modified biochar. Environ. Sci. Pollut. Res. 2018, 25, 11875-11883. [CrossRef]

10. Tariq, W.; Saifullah, M.; Anjum, T.; Javed, M.; Tayyab, N.; Shoukat, I. Removal of Heavy Metals from Chemical Industrial Wastewater Using Agro Based Bio-Sorbents. Acta Chem. Malays. 2018, 2, 9-14. [CrossRef]

11. Imtiaz, M.; Ashraf, M.; Rizwan, M.S.; Nawaz, M.A.; Mehmood, S.; Yousaf, B.; Yuan, Y.; Ditta, A.; Mumtaz, M.A.; Ali, M.; et al. Vanadium toxicity in chickpea (Cicer arietinum L.) grown in red soil: Effects on cell death, ROS and antioxidative systems. Ecotoxicol. Environ. Saf. 2018, 158, 139-144. [CrossRef]

12. Hettick, B.E.; Cañas-Carrell, J.E.; French, A.D.; Klein, D.M. Arsenic: A Review of the Element's Toxicity, Plant Interactions, and Potential Methods of Remediation. J. Agric. Food Chem. 2015, 63, 7097-7107. [CrossRef] [PubMed]

13. Isherwood, K.F. Mineral Fertilizer Use; IFA: Paris, France, 2000; ISBN 2950629938.

14. Smith, L.; Siciliano, G. A comprehensive review of constraints to improved management of fertilizers in China and mitigation of diffuse water pollution from agriculture. Agric. Ecosyst. Environ. 2015, 209, 15-25. [CrossRef]

15. Weithmann, N.; Möller, J.N.; Löder, M.G.J.; Piehl, S.; Laforsch, C.; Freitag, R. Organic fertilizer as a vehicle for the entry of microplastic into the environment. Sci. Adv. 2018, 4, eaap8060. [CrossRef]

16. Mosa, K.A.; Saadoun, I.; Kumar, K.; Helmy, M.; Dhankher, O.P. Potential Biotechnological Strategies for the Cleanup of Heavy Metals and Metalloids. Front. Plant Sci. 2016, 7, 303. [CrossRef] 
17. Zhao, X.; Liu, W.; Cai, Z.; Han, B.; Qian, T.; Zhao, D. An overview of preparation and applications of stabilized zero-valent iron nanoparticles for soil and groundwater remediation. Water Res. 2016, 100, 245-266. [CrossRef] [PubMed]

18. Lim, J.; Chew, L.; Choong, T.S.; Tezara, C.; Yazdi, M. Overview of Steel Slag Application and Utilization. MATEC Web Conf. 2016, 74, 26. [CrossRef]

19. Liu, C.; Shih, K.; Sun, C.; Wang, F. Oxidative degradation of propachlor by ferrous and copper ion activated persulfate. Sci. Total Environ. 2012, 416, 507-512. [CrossRef]

20. Hocheng, H.; Su, C.; Jadhav, U.U. Bioleaching of metals from steel slag by Acidithiobacillus thiooxidans culture supernatant. Chemosphere 2014, 117, 652-657. [CrossRef] [PubMed]

21. Pang, B.; Zhou, Z.; Xu, H. Utilization of carbonated and granulated steel slag aggregate in concrete. Constr. Build. Mater. 2015, 84, 454-467. [CrossRef]

22. Yüksel, I. A review of steel slag usage in construction industry for sustainable development. Environ. Dev. Sustain. 2016, 19, 369-384. [CrossRef]

23. Fujisawa, N.; Fukushima, M.; Yamamoto, M.; Iwai, H.; Komai, T.; Kawabe, Y.; Liu, D. Structural alterations of humic acid fractions in a steel slag-compost fertilizer during fertilization. Analysis by pyrolysis/methylation-gas chromatography/mass spectrometry. J. Anal. Appl. Pyrolysis 2012, 95, 126-133. [CrossRef]

24. Gómez-Nubla, L.; Aramendia, J.; De Vallejuelo, S.F.-O.; Carrero, J.A.; Madariaga, J.M. Focused ultrasound energy over steel slags as a fast tool to assess their environmental risk before and after their reuse in agriculture and civil constructions. Microchem. J. 2017, 132, 268-273. [CrossRef]

25. Wen, T.; Yang, L.; Dang, C.; Miki, T.; Bai, H.; Nagasaka, T. Effect of basic oxygen furnace slag on succession of the bacterial community and immobilization of various metal ions in acidic contaminated mine soil. J. Hazard. Mater. 2020, $388,121784$. [CrossRef] [PubMed]

26. Gwon, H.S.; Khan, M.I.; Alam, M.A.; Das, S.; Kim, P.J. Environmental risk assessment of steel-making slags and the potential use of LD slag in mitigating methane emissions and the grain arsenic level in rice (Oryza sativa L.). J. Hazard. Mater. 2018, 353, 236-243. [CrossRef] [PubMed]

27. White, B.; Tubana, B.S.; Babu, T.; Mascagni, H.; Agostinho, F.; Datnoff, L.E.; Harrison, S. Effect of Silicate Slag Application on Wheat Grown Under Two Nitrogen Rates. Plants 2017, 6, 47. [CrossRef]

28. Ning, D.; Liang, Y.; Liu, Z.; Xiao, J.; Duan, A. Impacts of Steel-Slag-Based Silicate Fertilizer on Soil Acidity and Silicon Availability and Metals-Immobilization in a Paddy Soil. PLoS ONE 2016, 11, e0168163. [CrossRef]

29. Das, S.; Jeong, S.T.; Das, S.; Kim, P.J. Composted Cattle Manure Increases Microbial Activity and Soil Fertility More Than Composted Swine Manure in a Submerged Rice Paddy. Front. Microbiol. 2017, 8, 1702. [CrossRef] [PubMed]

30. Piatak, N.M.; Seal, R.R., II; Hoppe, D.A.; Green, C.J.; Buszka, P.M. Geochemical Characterization of Iron and Steel Slag and Its Potential to Remove Phosphate and Neutralize Acid. Minerals 2019, 9, 468. [CrossRef]

31. Bodurtha, P.; Brassard, P. Neutralization of Acid by Steel-Making Slags. Environ. Technol. 2000, 21, 1271-1281. [CrossRef]

32. Dimitrova, S. Metal sorption on blast-furnace slag. Water Res. 1996, 30, 228-232. [CrossRef]

33. Ahmaruzzaman, M. Industrial wastes as low-cost potential adsorbents for the treatment of wastewater laden with heavy metals. Adv. Colloid Interface Sci. 2011, 166, 36-59. [CrossRef]

34. Dimitrova, S.; Mehandgiev, D. Lead removal from aqueous solutions by granulated blast-furnace slag. Water Res. 1998, 32, 3289-3292. [CrossRef]

35. Shafaghat, J.; Ghaemi, A. Comparison of $\mathrm{Pb}(\mathrm{II})$ Adsorption by Ground Granulated Blast-Furnace and Phosphorus Slags; Exploitation of RSM. Iran. J. Sci. Technol. Trans. A Sci. 2021, 1-13. [CrossRef]

36. Rai, P.K.; Lee, S.S.; Zhang, M.; Tsang, Y.F.; Kim, K.H. Heavy metals in food crops: Health risks, fate, mechanisms, and management. Environ. Int. 2019, 125, 365-385. [CrossRef] [PubMed]

37. Wu, C.; Dun, Y.; Zhang, Z.; Li, M.; Wu, G. Foliar application of selenium and zinc to alleviate wheat (Triticum aestivum L.) cadmium toxicity and uptake from cadmium-contaminated soil. Ecotoxicol. Environ. Saf. 2020, 190, 110091. [CrossRef]

38. Xu, D.; Gao, B.; Gao, L.; Zhou, H.; Zhao, X.; Yin, S. Characteristics of cadmium remobilization in tributary sediments in Three Gorges Reservoir using chemical sequential extraction and DGT technology. Environ. Pollut. 2016, 218, 1094-1101. [CrossRef] [PubMed]

39. Liu, G.; Meng, J.; Huang, Y.; Dai, Z.; Tang, C.; Xu, J. Effects of carbide slag, lodestone and biochar on the immobilization, plant uptake and translocation of As and Cd in a contaminated paddy soil. Environ. Pollut. 2020, 266, 115194. [CrossRef]

40. Wang, X.; Peng, B.; Tan, C.; Ma, L.; Rathinasabapathi, B. Recent advances in arsenic bioavailability, transport, and speciation in rice. Environ. Sci. Pollut. Res. 2015, 22, 5742-5750. [CrossRef] [PubMed]

41. Bakircioglu, D.; Kurtulus, Y.B.; Ibar, H. Investigation of trace elements in agricultural soils by BCR sequential extraction method and its transfer to wheat plants. Environ. Monit. Assess. 2010, 175, 303-314. [CrossRef]

42. Matong, J.M.; Nyaba, L.; Nomngongo, P.N. Fractionation of trace elements in agricultural soils using ultrasound assisted sequential extraction prior to inductively coupled plasma mass spectrometric determination. Chemosphere 2016, 154, $249-257$. [CrossRef]

43. Qi, Y.; Huang, B.; Darilek, J.L. Effect of Drying on Heavy Metal Fraction Distribution in Rice Paddy Soil. PLoS ONE 2014, 9, e97327. [CrossRef] 
44. Yang, J.; Wang, S.; Lu, Z.; Lou, S. Converter slag-coal cinder columns for the removal of phosphorous and other pollutants. J. Hazard. Mater. 2009, 168, 331-337. [CrossRef] [PubMed]

45. Castro, G.; Crusciol, C. Effects of superficial liming and silicate application on soil fertility and crop yield under rotation. Geoderma 2013, 195-196, 234-242. [CrossRef]

46. Gonzalo, M.J.; Lucena, J.J.; Hernández-Apaolaza, L. Effect of silicon addition on soybean (Glycine max) and cucumber (Cucumis sativus) plants grown under iron deficiency. Plant Physiol. Biochem. 2013, 70, 455-461. [CrossRef] [PubMed]

47. Richmond, K.E.; Sussman, M. Got silicon? The non-essential beneficial plant nutrient. Curr. Opin. Plant Biol. $2003,6,268-272$.

48. Wu, J.-W.; Shi, Y.; Zhu, Y.-X.; Wang, Y.-C.; Gong, H.-J. Mechanisms of Enhanced Heavy Metal Tolerance in Plants by Silicon: A Review. Pedosphere 2013, 23, 815-825. [CrossRef]

49. Fan, Y.; Li, Y.; Li, H.; Cheng, F. Evaluating heavy metal accumulation and potential risks in soil-plant systems applied with magnesium slag-based fertilizer. Chemosphere 2018, 197, 382-388. [CrossRef]

50. Chandio, A.A.; Jiang, Y.; Rehman, A.; Rauf, A. Short and long-run impacts of climate change on agriculture: An empirical evidence from China. Int. J. Clim. Chang. Strat. Manag. 2020, 12, 201-221. [CrossRef]

51. Gale, H.F.; Hu, D. Food Safety Pressures Push Integration in China's Agricultural Sector. Am. J. Agric. Econ. 2012, 94, 483-488. [CrossRef]

52. Wang, P.; Chen, H.; Kopittke, P.M.; Zhao, F.-J. Cadmium contamination in agricultural soils of China and the impact on food safety. Environ. Pollut. 2019, 249, 1038-1048. [CrossRef]

53. Yang, X.; Xia, L.; Li, J.; Dai, M.; Yang, G.; Song, S. Adsorption of As(III) on porous hematite synthesized from goethite concentrate. Chemosphere 2017, 169, 188-193. [CrossRef] [PubMed]

54. Du, Y.; Hu, X.-F.; Wu, X.-H.; Shu, Y.; Jiang, Y.; Yan, X.-J. Affects of mining activities on Cd pollution to the paddy soils and rice grain in Hunan province, Central South China. Environ. Monit. Assess. 2013, 185, 9843-9856. [CrossRef] [PubMed]

55. Meharg, C.; Meharg, A.A. Silicon, the silver bullet for mitigating biotic and abiotic stress, and improving grain quality, in rice? Environ. Exp. Bot. 2015, 120, 8-17. [CrossRef]

56. Annunziata, T.; Coll, V. Possible Uses of Steelmaking Slag in Agriculture: An Overview. In Material Recycling-Trends and Perspectives; IntechOpen: London, UK, 2012.

57. Ali, M.A.; Oh, J.H.; Kim, P.J. Evaluation of silicate iron slag amendment on reducing methane emission from flood water rice farming. Agric. Ecosyst. Environ. 2008, 128, 21-26. [CrossRef]

58. Ali, M.A.; Lee, C.H.; Lee, Y.B.; Kim, P.J. Silicate fertilization in no-tillage rice farming for mitigation of methane emission and increasing rice productivity. Agric. Ecosyst. Environ. 2009, 132, 16-22. [CrossRef]

59. Lee, C.H.; Kim, S.Y.; Villamil, M.B.; Pramanik, P.; Hong, C.O.; Kim, P.J. Different response of silicate fertilizer having electron acceptors on methane emission in rice paddy soil under green manuring. Biol. Fertil. Soils 2012, 48, 435-442. [CrossRef]

60. Wang, W.; Lai, D.Y.F.; Abid, A.A.; Neogi, S.; Xu, X.; Wang, C. Effects of Steel Slag and Biochar Incorporation on Active Soil Organic Carbon Pools in a Subtropical Paddy Field. Agronomy 2018, 8, 135. [CrossRef]

61. Wang, W.; Lai, D.; Wang, C.; Pan, T.; Zeng, C. Effects of rice straw incorporation on active soil organic carbon pools in a subtropical paddy field. Soil Tillage Res. 2015, 152, 8-16. [CrossRef]

62. Luyckx, M.; Hausman, J.-F.; Lutts, S.; Guerriero, G. Silicon and Plants: Current Knowledge and Technological Perspectives. Front. Plant Sci. 2017, 8, 411. [CrossRef]

63. Crusciol, C.A.; Artigiani, A.C.; Arf, O.; Filho, A.C.C.; Soratto, R.P.; Nascente, A.S.; Alvarez, R.C. Soil fertility, plant nutrition, and grain yield of upland rice affected by surface application of lime, silicate, and phosphogypsum in a tropical no-till system. Catena 2016, 137, 87-99. [CrossRef]

64. Ning, D.; Liang, Y.; Song, A.; Duan, A.; Liu, Z. In situ stabilization of heavy metals in multiple-metal contaminated paddy soil using different steel slag-based silicon fertilizer. Environ. Sci. Pollut. Res. 2016, 23, 23638-23647. [CrossRef]

65. Hwang, S.F.; Strelkov, S.E.; Gossen, B.D.; Turnbull, G.D.; Ahmed, H.U.; Manolii, V.P. Soil treatments and amendments for amelioration of clubroot of canola. Can. J. Plant Sci. 2011, 91, 999-1010. [CrossRef]

66. Moraes, J.; Tashima, M.; Akasaki, J.; Melges, J.; Monzó, J.; Borrachero, M.; Soriano, L.; Payá, J. Effect of sugar cane straw ash (SCSA) as solid precursor and the alkaline activator composition on alkali-activated binders based on blast furnace slag (BFS). Constr. Build. Mater. 2017, 144, 214-224. [CrossRef]

67. Yip, C.K.; Lukey, G.C.; Provis, J.L.; Van Deventer, J.S. Effect of calcium silicate sources on geopolymerisation. Cem. Concr. Res. 2008, 38, 554-564. [CrossRef]

68. Qin, G.; Niu, Z.; Yu, J.; Li, Z.; Ma, J.; Xiang, P. Soil heavy metal pollution and food safety in China: Effects, sources and removing technology. Chemosphere 2021, 267, 129205. [CrossRef]

69. Zhang, X.-N.; Guo, Q.-P.; Shen, X.-X.; Yu, S.-W.; Qiu, G.-Y. Water quality, agriculture and food safety in China: Current situation, trends, interdependencies, and management. J. Integr. Agric. 2015, 14, 2365-2379. [CrossRef]

70. Jiang, J.; $\mathrm{Xu}, \mathrm{R} .-\mathrm{K}$. Application of crop straw derived biochars to $\mathrm{Cu}(\mathrm{II})$ contaminated Ultisol: Evaluating role of alkali and organic functional groups in Cu(II) immobilization. Bioresour. Technol. 2013, 133, 537-545. [CrossRef] [PubMed]

71. Masud, M.; Li, J.-Y.; Xu, R.-K. Use of Alkaline Slag and Crop Residue Biochars to Promote Base Saturation and Reduce Acidity of an Acidic Ultisol. Pedosphere 2014, 24, 791-798. [CrossRef]

72. Gao, R.; Fu, Q.; Hu, H.; Wang, Q.; Liu, Y.; Zhu, J. Highly-effective removal of Pb by co-pyrolysis biochar derived from rape straw and orthophosphate. J. Hazard. Mater. 2019, 371, 191-197. [CrossRef] 
73. He, H.; Tam, N.F.; Yao, A.; Qiu, R.; Li, W.C.; Ye, Z. Growth and Cd uptake by rice (Oryza sativa) in acidic and Cd-contaminated paddy soils amended with steel slag. Chemosphere 2017, 189, 247-254. [CrossRef]

74. Liu, H.; Yang, F.; Zheng, Y.; Kang, J.; Qu, J.; Chen, J.P. Improvement of metal adsorption onto chitosan/Sargassum sp. composite sorbent by an innovative ion-imprint technology. Water Res. 2011, 45, 145-154. [CrossRef]

75. Yu, H.-Y.; Ding, X.; Li, F.; Wang, X.; Zhang, S.; Yi, J.; Liu, C.; Xu, X.; Wang, Q. The availabilities of arsenic and cadmium in rice paddy fields from a mining area: The role of soil extractable and plant silicon. Environ. Pollut. 2016, 215, 258-265. [CrossRef]

76. Maguffin, S.C.; Abu-Ali, L.; Tappero, R.V.; Pena, J.; Rohila, J.S.; McClung, A.M.; Reid, M.C. Influence of manganese abundances on iron and arsenic solubility in rice paddy soils. Geochim. Cosmochim. Acta 2020, 276, 50-69. [CrossRef]

77. Yamaguchi, N.; Nakamura, T.; Dong, D.; Takahashi, Y.; Amachi, S.; Makino, T. Arsenic release from flooded paddy soils is influenced by speciation, Eh, $\mathrm{pH}$, and iron dissolution. Chemosphere 2011, 83, 925-932. [CrossRef]

78. Tang, X.-Y.; Zhu, Y.-G.; Shan, X.-Q.; McLaren, R.; Duan, J. The ageing effect on the bioaccessibility and fractionation of arsenic in soils from China. Chemosphere 2007, 66, 1183-1190. [CrossRef] [PubMed]

79. Wang, M.; Lan, X.; Xu, X.; Fang, Y.; Singh, B.P.; Sardans, J.; Romero, E.; Peñuelas, J.; Wang, W. Steel slag and biochar amendments decreased $\mathrm{CO} 2$ emissions by altering soil chemical properties and bacterial community structure over two-year in a subtropical paddy field. Sci. Total Environ. 2020, 740, 140403. [CrossRef]

80. Ali, S.; Farooq, M.A.; Yasmeen, T.; Hussain, S.; Arif, M.S.; Abbas, F.; Bharwana, S.A.; Zhang, G. The influence of silicon on barley growth, photosynthesis and ultra-structure under chromium stress. Ecotoxicol. Environ. Saf. 2013, 89, 66-72. [CrossRef]

81. Wang, W.Q.; Li, P.F.; Zeng, C.S.; Tong, C. Evaluation of Silicate Iron Slag as a Potential Methane Mitigating Method. Adv. Mater. Res. 2012, 468-471, 1626-1630. [CrossRef]

82. Major, J.; Lehmann, J.; Rondon, M.; Goodale, C. Fate of soil-applied black carbon: Downward migration, leaching and soil respiration. Glob. Chang. Biol. 2010, 16, 1366-1379. [CrossRef]

83. Singh, B.P.; Fang, Y.; Boersma, M.; Collins, D.; Van Zwieten, L.; Macdonald, L.M. In Situ Persistence and Migration of Biochar Carbon and Its Impact on Native Carbon Emission in Contrasting Soils under Managed Temperate Pastures. PLoS ONE 2015, 10, e0141560. [CrossRef]

84. Okuda, T.; Lin, F.; Nakai, S.; Nishijima, W.; Katayama, Y.; Okada, M. Effect of changes in the physicochemical properties of sand-alternatives on bacterial community structure in coastal sediments. Ecol. Eng. 2016, 88, 177-185. [CrossRef]

85. Song, X.; Li, L.; Zheng, J.; Pan, G.; Zhang, X.; Zheng, J.; Hussain, Q.; Han, X.; Yu, X. Sequestration of maize crop straw C in different soils: Role of oxyhydrates in chemical binding and stabilization as recalcitrance. Chemosphere 2012, 87, 649-654. [CrossRef]

86. Marstorp, H.; Guan, X.; Gong, P. Relationship between dsDNA, chloroform labile C and ergosterol in soils of different organic matter contents and pH. Soil Biol. Biochem. 2000, 32, 879-882. [CrossRef]

87. Chen, J.; Liu, X.; Zheng, J.; Zhang, B.; Lu, H.; Chi, Z.; Pan, G.; Li, L.; Zheng, J.; Zhang, X.; et al. Biochar soil amendment increased bacterial but decreased fungal gene abundance with shifts in community structure in a slightly acid rice paddy from Southwest China. Appl. Soil Ecol. 2013, 71,33-44. [CrossRef]

88. Singh, J.; Kalamdhad, A.S. Effect of carbide sludge (lime) on bioavailability and leachability of heavy metals during rotary drum composting of water hyacinth. Chem. Speciat. Bioavailab. 2014, 26, 76-84. [CrossRef]

89. Tang, J.; Zhang, L.; Zhang, J.; Ren, L.; Zhou, Y.; Zheng, Y.; Luo, L.; Yang, Y.; Huang, H.; Chen, A. Physicochemical features, metal availability and enzyme activity in heavy metal-polluted soil remediated by biochar and compost. Sci. Total Environ. 2020, 701, 134751. [CrossRef]

90. Cheng, S.; Chen, T.; Xu, W.; Huang, J.; Jiang, S.; Yan, B. Application Research of Biochar for the Remediation of Soil Heavy Metals Contamination: A Review. Molecules 2020, 25, 3167. [CrossRef]

91. Medyńska-Juraszek, A.; Ćwielag-Piasecka, I. Effect of Biochar Application on Heavy Metal Mobility in Soils Impacted by Copper Smelting Processes. Pol. J. Environ. Stud. 2020, 29, 1749-1757. [CrossRef]

92. Tu, C.; Wei, J.; Guan, F.; Liu, Y.; Sun, Y.; Luo, Y. Biochar and bacteria inoculated biochar enhanced Cd and Cu immobilization and enzymatic activity in a polluted soil. Environ. Int. 2020, 137, 105576. [CrossRef] [PubMed]

93. Bashir, S.; Salam, A.; Rehman, M.; Khan, S.; Gulshan, A.B.; Iqbal, J.; Shaaban, M.; Mehmood, S.; Zahra, A.; Hu, H. Effective Role of Biochar, Zeolite and Steel Slag on Leaching Behavior of Cd and Its Fractionations in Soil Column Study. Bull. Environ. Contam. Toxicol. 2019, 102, 567-572. [CrossRef] [PubMed]

94. Yuvaraja, G.; Pang, Y.; Chen, D.-Y.; Kong, L.-J.; Mehmood, S.; Subbaiah, M.V.; Rao, D.S.; Pavuluri, C.M.; Wen, J.-C.; Reddy, G.M. Modification of chitosan macromolecule and its mechanism for the removal of $\mathrm{Pb}$ (II) ions from aqueous environment. Int. J. Biol. Macromol. 2019, 136, 177-188. [CrossRef] [PubMed]

95. Irshad, S.; Xie, Z.; Wang, J.; Nawaz, A.; Luo, Y.; Wang, Y.; Mehmood, S. Faheem Indigenous strain Bacillus XZM assisted phytoremediation and detoxification of arsenic in Vallisneria denseserrulata. J. Hazard. Mater. 2020, 381, 120903. [CrossRef] [PubMed]

96. Rizwan, M.; Mostofa, M.G.; Ahmad, M.Z.; Zhou, Y.; Adeel, M.; Mehmood, S.; Javed, R.; Imtiaz, M.; Aziz, O.; Ikram, M.; et al. Hydrogen sulfide enhances rice tolerance to nickel through the prevention of chloroplast damage and the improvement of nitrogen metabolism under excessive nickel. Plant Physiol. Biochem. 2019, 138, 100-111. [CrossRef] [PubMed] 
97. Bashir, S.; Ali, U.; Shaaban, M.; Gulshan, A.B.; Iqbal, J.; Khan, S.; Husain, A.; Ahmed, N.; Mehmood, S.; Kamran, M.; et al. Role of sepiolite for cadmium (Cd) polluted soil restoration and spinach growth in wastewater irrigated agricultural soil. J. Environ. Manag. 2020, 258, 110020. [CrossRef]

98. Yang, L.; Wei, T.; Li, S.; Lv, Y.; Miki, T.; Yang, L.; Nagasaka, T. Immobilization persistence of Cu, Cr, Pb, Zn ions by the addition of steel slag in acidic contaminated mine soil. J. Hazard. Mater. 2021, 412, 125176. [CrossRef]

99. Lü, R.; Xi, Q.; Li, T.; Li, R.; Zhang, X.; Liu, J.; Fan, C.; Feng, J.; Zhang, L.; Wang, Z.; et al. Adsorption equilibrium, kinetics, and dynamic separation of $\mathrm{Ca}^{2+}$ and $\mathrm{Mg}^{2+}$ ions from phosphoric acid-nitric acid aqueous solution by strong acid cation resin. Chin. J. Chem. Eng. 2019, 27, 2930-2936. [CrossRef]

100. Yang, L.; Wen, T.; Wang, L.; Miki, T.; Bai, H.; Lu, X.; Yu, H.; Nagasaka, T. The stability of the compounds formed in the process of removal $\mathrm{Pb}(\mathrm{II}), \mathrm{Cu}(\mathrm{II})$ and $\mathrm{Cd}(\mathrm{II})$ by steelmaking slag in an acidic aqueous solution. J. Environ. Manag. 2019, 231, 41-48. [CrossRef]

101. Chen, G.; Yang, L.; Chen, J.; Miki, T.; Li, S.; Bai, H.; Nagasaka, T. Competitive mechanism and influencing factors for the simultaneous removal of $\mathrm{Cr}(\mathrm{III})$ and $\mathrm{Zn}$ (II) in acidic aqueous solutions using steel slag: Batch and column experiments. J. Clean. Prod. 2019, 230, 69-79. [CrossRef]

102. Hiltunen, R.; Hiltunen, A. Environmental aspects of the utilization of steel industry slags. In Proceedings of the Proceedings of VII International Conference on Molten Slags, Fluxes and Salts, Cap Town, South Africa, 25-28 January 2004.

103. Chand, S.; Paul, B.; Kumar, M. An Overview of Use of Linz-Donawitz (LD) Steel Slag in Agriculture. Curr. World Environ. 2015, 10, 975-984. [CrossRef]

104. Wang, X.; Wang, G.; Guo, T.; Xing, Y.; Mo, F.; Wang, H.; Fan, J.; Zhang, F. Effects of plastic mulch and nitrogen fertilizer on the soil microbial community, enzymatic activity and yield performance in a dryland maize cropping system. Eur. J. Soil Sci. 2021, 72, 400-412. [CrossRef]

105. Wang, X.; Fan, J.; Xing, Y.; Xu, G.; Wang, H.; Deng, J.; Wang, Y.; Zhang, F.; Li, P.; Li, Z. The effects of mulch and nitrogen fertilizer on the soil environment of crop plants. Adv. Agron. 2019, 153, 121-173. [CrossRef] 